\title{
The Hydrogen Ion Concentration of Sea Water in its Relation to Photosynthetic Changes.
}

\author{
PART III. \\ By \\ W. R. G. Atkins, O.B.E., Sc.D., F.I.C., \\ Head of the Department of General Physiology at the Plymouth Laboratory.
}

With Figures $1-4$ in the Text.

\section{INTRODUCTION.}

THE present paper is a continuation of the work already published* under the above general title and should be considered in relation to the results previously recorded. The method of performing the measurements remained unchanged; xylenol blue was used to check the determinations made with cresol red in the more alkaline regions-namely, around $\mathrm{pH}$ 8.24. The water was tested immediately after being drawn, or within a few hours, unless otherwise stated in the tables.

The results obtained are tabulated for reference, but since the seasonal changes are in a general way similar to those of 1921-22 they have only been shown graphically in four figures, which are of interest as they illustrate the differences between the years and the variation of $\mathrm{pH}$ with depth.

Salinity determinations, made at the Government Chemist's Laboratory, were used to apply small corrections to the $\mathrm{pH}$ values of the $\mathrm{L}$ series where necessary, but since they are published as part of the International Hydrographic Investigations they are omitted here.

\section{THE RELATION OF THE WATER OF PLYMOUTH SOUND TO THAT OF THE OPEN SEA THROUGHOUT THE YEAR.}

In this series perhaps the most noticeable differences as compared with the previous year are the low $\mathrm{pH}$ values for March 12th, which extend right out to the Eddystone, L 5, instead of ceasing at the Breakwater,

* Journ. Mar. Biol. Assoc., Vol. XII, No. 4, pp. 717-771, 1922, and Vol. XIII, No. 1, pp. 93-118, 1923. 
L 2. The samples of the 14th also show this, but to a much smaller degree; while those of the 21st are normal.

The salinity determinations indicate that the effect was due to the great volume of fresh water coming down the rivers.

Unfortunately a complete series was not obtained in May, but photosynthetic activity must then have been very great, since the high values $\mathrm{pH} 8.23$ were found at $\mathrm{L} 3$ and $\mathrm{L} 4$, both at the surface and at the bottom -namely, at 45 and 50 metres depth respéctively. The $\mathrm{E} 1$ depth series contains no such high values for these depths, but between Sardinia and Italy, Palitzsch records $\mathrm{pH} 8.23$ at the surface and 8.21 at 100 metres.

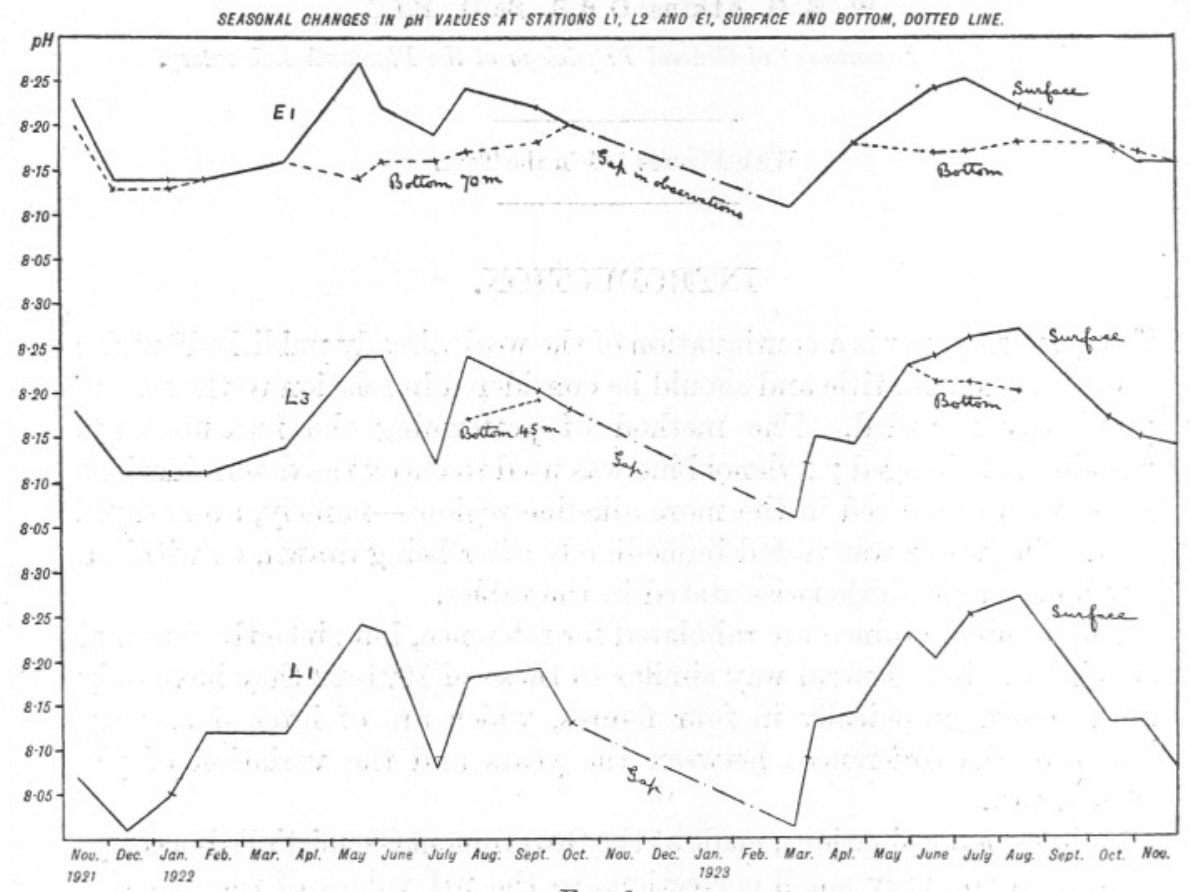

FIG. 1.

The July values for the $\mathrm{L}$ series are markedly different from those of the previous year. In 1922 the wet and stormy end of June caused the July $\mathrm{pH}$ values to be low, abnormally low it is probable, viz. $\mathrm{pH} 8.08$ and $\mathrm{pH} 8.12$ for $\mathrm{L} 1$ and $\mathrm{L} 3$, as compared with $\mathrm{pH} 8.25$ and $\mathrm{pH} 8.26$ respectively for 1923. This drop in July may be appreciated from a study of Fig. 1, which shows the $\mathrm{pH}$ values for L 1, L 3, and E 1 from November, 1921, to November, 1923, inclusive. Bottom values are shown by a dotted line. The water accordingly remained uniformly alkaline at the stations throughout the summer. The relation between this and the seasonal distribution of sunshine is shown in Fig. 4. 
March 12th. March 14th. March 21st. March 28th.

\begin{tabular}{|c|c|c|c|c|c|c|c|}
\hline Station. & $t^{\circ} \mathrm{C}$. & $\mathrm{pH}$ & $t^{\circ} \mathrm{C}$. & $\mathrm{pH}$ & $\mathrm{pH}$ & $t^{\circ} \mathrm{C}$ & $\mathrm{pH}$ \\
\hline L 1 & $8 \cdot 7$ & $8 \cdot 01$ & $8 \cdot 6$ & $7 \cdot 98$ & $8 \cdot 09$ & $9 \cdot 6$ & $8 \cdot 13$ \\
\hline L 2 & $8 \cdot 8$ & 8.01 & $8 \cdot 8$ & 8.09 & 8.09 & $9 \cdot 4$ & $8 \cdot 13$ \\
\hline L 3 & $9 \cdot 1$ & - & $9 \cdot 0$ & 8.09 & $8 \cdot 12$ & $9 \cdot 25$ & $8 \cdot 15$ \\
\hline L 4 & $9 \cdot 1$ & $8 \cdot 01$ & $9 \cdot 1$ & $8 \cdot 08^{*}$ & $8 \cdot 12$ & $9 \cdot 2$ & $8 \cdot 14$ \\
\hline L 5 & $9 \cdot 1$ & $8 \cdot 03$ & $9 \cdot 1$ & - & $8 \cdot 12$ & $9 \cdot 3$ & $8 \cdot 14$ \\
\hline L 6 & $9 \cdot 2$ & $8 \cdot 11$ & - & - & - & - & - \\
\hline E 1 & $9 \cdot 3$ & $8 \cdot 11$ & $9 \cdot 6$ & $8 \cdot 12$ & - & - & - \\
\hline
\end{tabular}

$\mathrm{pH}$ determined on 13th. * $\quad * \mathrm{pH}$ determined on 15th, rest on 16th.

April 24th. May 22nd. May 31st. June 19th. July 10th \& 12th.

\begin{tabular}{ccccccccc} 
Station. & $t{ }^{\circ} \mathrm{C}$. & $\mathrm{pH}$ & $\mathrm{t}{ }^{\circ} \mathrm{C}$. & $\mathrm{pH}$ & $\mathrm{t}{ }^{\circ} \mathrm{C}$. & $\mathrm{pH}$ & $t{ }^{\circ} \mathrm{C}$. & $\mathrm{pH}$ \\
$\mathrm{L} 1$ & $9 \cdot 7$ & $8 \cdot 14$ & $10 \cdot 8$ & - & $12 \cdot 6$ & $8 \cdot 20$ & $16 \cdot 65$ & $8 \cdot 25$ \\
$\mathrm{~L} 2$ & $9 \cdot 7$ & $8 \cdot 10$ & $10 \cdot 8$ & - & $12 \cdot 45$ & $8 \cdot 24$ & $15 \cdot 85$ & $8 \cdot 25$ \\
$\mathrm{~L} 3$ & $9 \cdot 5$ & $8 \cdot 14$ & $10 \cdot 7$ & $8 \cdot 23 \dagger$ & $12 \cdot 35$ & $8 \cdot 24$ & $16 \cdot 7$ & $8 \cdot 26$ \\
$\mathrm{~L} 4$ & $9 \cdot 7$ & $8 \cdot 13$ & $10 \cdot 4$ & $8 \cdot 23 \dagger$ & $12 \cdot 55$ & $8 \cdot 24$ & $16 \cdot 6$ & $8 \cdot 25$ \\
$\mathrm{~L} 5$ & $9 \cdot 7$ & $8 \cdot 16$ & $10 \cdot 7$ & - & $12 \cdot 6$ & $8 \cdot 24$ & $15 \cdot 6$ & $8 \cdot 23$ \\
$\mathrm{~L} 6$ & $9 \cdot 9$ & $8 \cdot 16$ & $10 \cdot 8$ & - & $12 \cdot 7$ & $8 \cdot 24$ & $16 \cdot 8$ & $8 \cdot 25$ \\
E 1 & $10 \cdot 1$ & $8 \cdot 18$ & $10 \cdot 9$ & - & $12 \cdot 8$ & $8 \cdot 24$ & $16 \cdot 6$ & $8 \cdot 25$ \\
pH determined on 26th. & \multicolumn{7}{c}{ Tame at bottom. }
\end{tabular}

August 15th. Sept. 13th. October. November 7th.

$\begin{array}{cccccccc}\text { Station. } & \mathrm{t}^{\circ} \mathrm{C} . & \mathrm{pH} & \mathrm{t}^{\circ} \mathrm{C} . & \mathrm{t}{ }^{\circ} \mathrm{C} . & \mathrm{pH} & \mathrm{t}{ }^{\circ} \mathrm{C} . & \mathrm{pH} \\ \text { L 1 } & 15 \cdot 4 & 8 \cdot 27 & 14 \cdot 8 & 13 \cdot 0 & 8 \cdot 13 & 11 \cdot 0 & 8 \cdot 13 \\ \text { L 2 } & 14 \cdot 5 & 8 \cdot 26 & 14 \cdot 6 & 12 \cdot 8 & 8 \cdot 14 & 11 \cdot 3 & 8 \cdot 14 \\ \text { L 3 } & 16 \cdot 3 & 8 \cdot 27 & 14 \cdot 4 & 13 \cdot 1 & 8 \cdot 17 & 12 \cdot 1 & - \\ \text { L 4 } & 16 \cdot 7 & 8 \cdot 26 & 15 \cdot 1 & 13 \cdot 3 & 8 \cdot 17 & 12 \cdot 1 & 8 \cdot 17 \\ \text { L 5 } & 16 \cdot 2 & 8 \cdot 26 & 14 \cdot 7 & 13 \cdot 6 & 8 \cdot 17 & 12 \cdot 0 & - \\ \text { L 6 } & 17 \cdot 0 & 8 \cdot 22 & 14 \cdot 6 & 13 \cdot 6 & 8 \cdot 18 & 11 \cdot 9 & - \\ \text { E 1 } & 16 \cdot 7 & 8 \cdot 22 & 15 \cdot 0 & 13 \cdot 0 & 8 \cdot 18 & 12 \cdot 1 & 8 \cdot 16 \\ & & & & & & \mathrm{pH} \text { determined on 9th. }\end{array}$

December 10th. January 2nd, 1924.

$\begin{array}{crccc}\text { Station. } & \mathrm{t}^{\circ} \mathrm{C} . & \mathrm{pH} & \mathrm{t}^{\circ} \mathrm{C} . & \mathrm{pH} \\ \text { L 1 } & 9 \cdot 1 & 8 \cdot 06 & 8 \cdot 9 & 8 \cdot 02 \\ \text { L 2 } & 9 \cdot 2 & 8 \cdot 10 & 9 \cdot 0 & 8 \cdot 03 \\ \text { L 3 } & 9 \cdot 2 & 8 \cdot 14 & 9 \cdot 0 & 8 \cdot 09 \\ \text { L 4 } & 9 \cdot 4 & 8 \cdot 15 & 9 \cdot 0 & 8 \cdot 09 \\ \text { L 5 } & 9 \cdot 9 & 8 \cdot 16 & 9 \cdot 1 & 8 \cdot 14 \\ \text { L 6 } & 10 \cdot 3 & 8 \cdot 16 & 9 \cdot 1 & 8 \cdot 14 \\ \text { E 1 } & 10 \cdot 2 & 8 \cdot 16 & 9 \cdot 4 & 8 \cdot 16\end{array}$




\section{THE SEASONAL CHANGES IN THE HYDROGEN ION CONCEN- TRATION OF THE OPEN SEA AT VARIOUS STATIONS AND DEPTHS.}

The monthly visits to $\mathrm{E} 1$ were continued during 1923 , but no $\mathrm{pH}$ values were determined for September or May. The depth series results are tabulated here and shown in Fig. 2.

When compared with 1922 the 1923 results are noticeable chiefly for the absence of the depression in July, as may be seen in Fig. 1. The results for November, 1921, which gave high values owing to the exceptionally sunny autumn, are also markedly above those for 1922 and 1923.

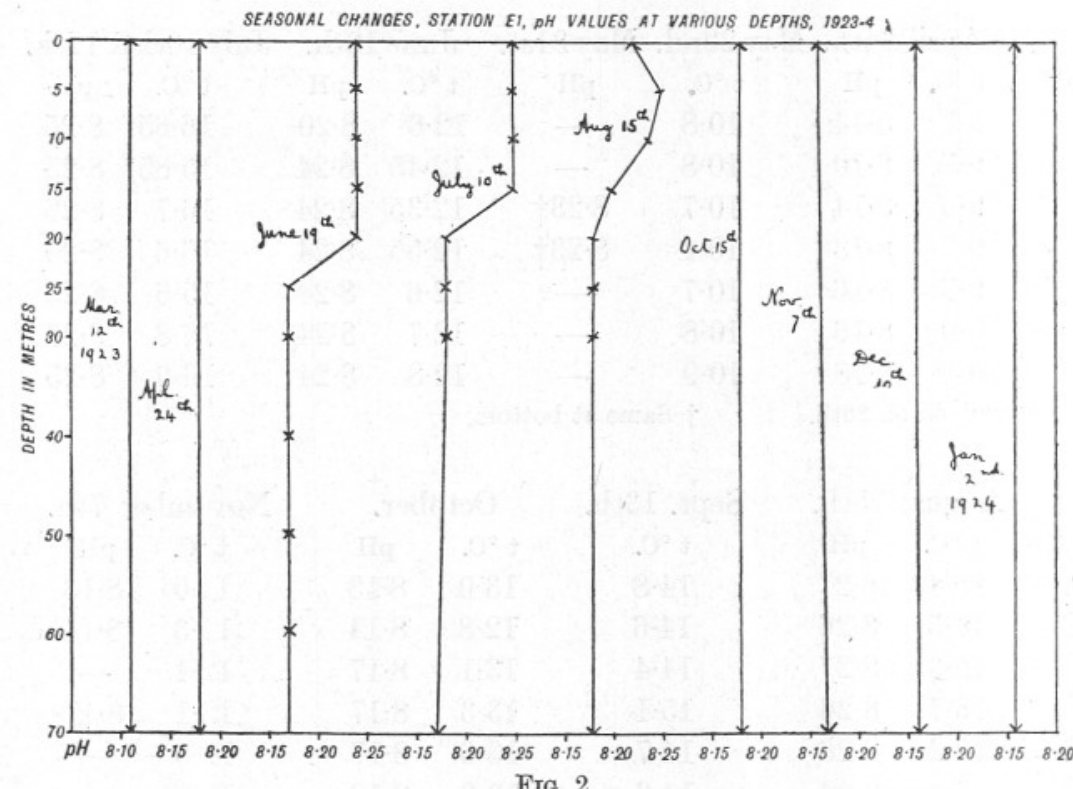

Furthermore, the 1922 maximum occurred in May, with a secondary one early in August; whereas in 1923, though June gave high values, the maximum was in July. No observations were made in May, however ; but from the form of the depth series curves shown in Fig. 2 it is impossible to say whether the maximum had passed by June 19th. As in 1922, the bottom values at $\mathrm{E} 1$ rose slightly during the summer to a maximum $\mathrm{pH} 8 \cdot 18$, at which on October 15th and April 24th the water column was uniform from top to bottom. In 1922 the October value was $\mathrm{pH}$ $8 \cdot 20$, which corresponds to a 3 per cent difference in hydroxyl ion concentration in favour of 1922.

As regards the question as to whether the July value was truly the maximum, it is of interest to note that the phosphate content at E 1 
was a minimum in July, which points to the maximum algal development having occurred by that time. This does not necessarily indicate that July was also the true maximum for $\mathrm{pH}$ value, rather than May, but it lends support to that view.

As in 1922, the curves of the depth series, Fig. 2, are noticeably of different form during the summer months, when the more alkaline warm water is found nearest the surface, where it remains unmixed with the deeper and colder water until the autumn. This question of the mixing of the water is considered in a separate paper.

The $\mathrm{pH}$ values and temperatures are tabulated below, as are also similar results for stations $\mathrm{E} 2, \mathrm{E} 3, \mathrm{~N} 1$ and $\mathrm{N} 2$. In Fig. 3 the $\mathrm{pH}$ depth series for these and $\mathrm{E} 1$ is shown; the gradients at the different stations may be grouped according to position, those for the coastal stations $\mathrm{E} 3$ and $\mathrm{N} 2$ being nowhere steep; whereas those far from land, $\mathrm{E} 1, \mathrm{E} 2$, and $\mathrm{N} 1$, are well marked.

\begin{tabular}{|c|c|c|c|c|c|c|c|c|}
\hline $\begin{array}{l}\text { E 1. I } \\
\text { Depth }\end{array}$ & & & Ap & En. & Jun & th. & July & th. \\
\hline$n$ metres. & $\mathrm{t}^{\circ} \mathrm{C}$ & $\mathrm{pH}$ & $t^{\circ} \mathrm{C}$ & $\mathrm{pH}$ & $t^{\circ} \mathrm{C}$ & $\mathrm{pH}$ & $t^{\circ} \mathrm{C}$ & $\mathrm{pH}$ \\
\hline 0 & $9 \cdot 32$ & $8 \cdot 11$ & $10 \cdot 1$ & $8 \cdot 18$ & $12 \cdot 8$ & $8 \cdot 24$ & $16 \cdot 6$ & $8 \cdot 25$ \\
\hline 5 & $9 \cdot 22$ & - & $10 \cdot 04$ & - & $12 \cdot 66$ & $8 \cdot 24$ & $16 \cdot 38$ & $8 \cdot 25$ \\
\hline 10 & - & - & - & - & $12 \cdot 48$ & $8 \cdot 24$ & $16 \cdot 28$ & $8 \cdot 25$ \\
\hline 15 & - & - & $9 \cdot 87$ & - & $12 \cdot 40$ & $8 \cdot 24$ & $14 \cdot 83$ & $8 \cdot 25$ \\
\hline 20 & - & - & - & - & $12 \cdot 34$ & $8 \cdot 24$ & $12 \cdot 19$ & $8 \cdot 18$ \\
\hline 25 & $9 \cdot 24$ & - & $9 \cdot 89$ & - & $11 \cdot 20$ & $8 \cdot 17$ & $12 \cdot 01$ & $8 \cdot 18$ \\
\hline 30 & - & - & - & - & $11 \cdot 20$ & $8 \cdot 17$ & 11.97 & $8 \cdot 18$ \\
\hline 40 & - & - & - & - & $11 \cdot 16$ & - & $11 \cdot 94$ & - \\
\hline 50 & $9 \cdot 22$ & - & $9 \cdot 87$ & - & $11 \cdot 16$ & $8 \cdot 17$ & $11 \cdot 84$ & 一 \\
\hline 60 & - & - & - & - & $11 \cdot 15$ & $8 \cdot 17$ & $11 \cdot 84$ & - \\
\hline 70 & $9 \cdot 20$ & $8 \cdot 11$ & $9 \cdot 79$ & $8 \cdot 18$ & $11 \cdot 14$ & $8 \cdot 17$ & $11 \cdot 87$ & $8 \cdot 17$ \\
\hline
\end{tabular}

$\mathrm{pH}$ determined on 13th. $\mathrm{pH}$ determined on $26 \mathrm{th}$.

\begin{tabular}{|c|c|c|c|c|c|c|c|c|}
\hline E 1 & \multicolumn{2}{|c|}{ Aug. 15th. } & \multicolumn{2}{|c|}{ Sept. 13th. } & \multicolumn{2}{|c|}{ Oct. 15th. } & \multicolumn{2}{|c|}{ Nov. 7th. } \\
\hline $\begin{array}{c}\text { Depth. } \\
0\end{array}$ & $\begin{array}{r}\mathrm{t}^{\circ} \mathrm{C} . \\
16.75\end{array}$ & $\begin{array}{l}\mathrm{pH} \\
8 \cdot 22\end{array}$ & $\begin{array}{l}t^{\circ} \mathrm{C} . \\
15 \cdot 0\end{array}$ & pH & $\begin{array}{l}t^{\circ} \mathrm{C} . \\
13 \cdot 0\end{array}$ & $\begin{array}{l}\mathrm{pH} \\
8 \cdot 18\end{array}$ & $\begin{array}{l}t^{\circ} \mathrm{C} . \\
12 \cdot 15\end{array}$ & $\begin{array}{l}\mathrm{pH} \\
8 \cdot 16\end{array}$ \\
\hline 5 & $16 \cdot 52$ & $8 \cdot 25$ & $14 \cdot 98$ & - & $13 \cdot 48$ & - & $12 \cdot 34$ & - \\
\hline 10 & $16 \cdot 28$ & $8 \cdot 24$ & $14 \cdot 32$ & 一 & $13 \cdot 36$ & - & - & - \\
\hline 15 & $12 \cdot 96$ & $8 \cdot 20$ & 13.59 & 一 & $13 \cdot 38$ & - & - & 一 \\
\hline 20 & $12 \cdot 70$ & $8 \cdot 18$ & $13 \cdot 33$ & 一 & $13 \cdot 46$ & - & - & 一 \\
\hline 25 & $12 \cdot 50$ & $8 \cdot 18$ & $13 \cdot 30$ & 一 & $13 \cdot 43$ & 一 & $12 \cdot 33$ & - \\
\hline 30 & $12 \cdot 50$ & $8 \cdot 18$ & $13 \cdot 25$ & - & $13 \cdot 35$ & - & - & 一 \\
\hline 40 & $12 \cdot 50$ & - & $13 \cdot 25$ & - & $13 \cdot 35$ & 一 & - & - \\
\hline 50 & $12 \cdot 46$ & - & $13 \cdot 25$ & 一 & $13 \cdot 35$ & 一 & - & - \\
\hline 60 & - & - & - & - & - & - & - & - \\
\hline 70 & $12 \cdot 46$ & $8 \cdot 18$ & $13 \cdot 25$ & - & $13 \cdot 40$ & $8 \cdot 18$ & $\begin{array}{l}12 \cdot 32 \\
\text { determ }\end{array}$ & $\begin{array}{l}8 \cdot 17 \\
\text { ned on }\end{array}$ \\
\hline
\end{tabular}




\begin{tabular}{|c|c|c|c|c|}
\hline E 1 & \multicolumn{2}{|c|}{ Dec. 10th, 1923.} & \multicolumn{2}{|c|}{ Jan. 2nd, 1824.} \\
\hline Depth. & $\mathrm{t}^{\circ} \mathrm{C}$ & $\mathrm{pH}$ & $t^{\circ} \mathrm{C}$ & $\mathrm{pH}$ \\
\hline 0 & $10 \cdot 2$ & $8 \cdot 16$ & $9 \cdot 45$ & $8 \cdot 16$ \\
\hline 5 & $10 \cdot 40$ & - & $9 \cdot 51$ & - \\
\hline 25 & $10 \cdot 35$ & - & $9 \cdot 52$ & - \\
\hline 70 & $10 \cdot 40$ & $8 \cdot 16$ & $9 \cdot 51$ & $8 \cdot 16$ \\
\hline
\end{tabular}

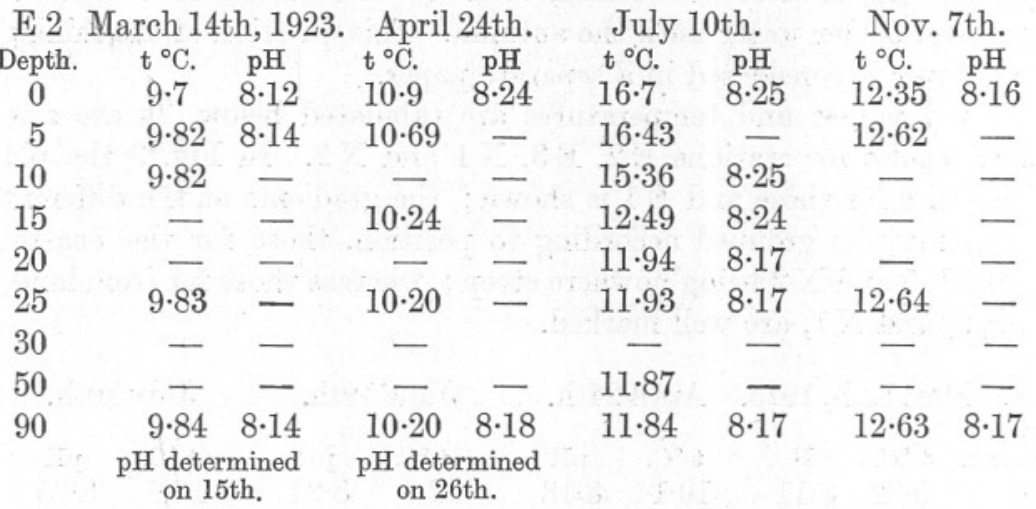

\begin{tabular}{ccccccc} 
E 3 & \multicolumn{3}{c}{ April 25th, 1923. } & \multicolumn{2}{c}{ July 11th. } & \multicolumn{2}{c}{ Nov. 8th. } \\
Depth. & $\begin{array}{c}\mathrm{t}^{\circ} \mathrm{C} . \\
\mathrm{oH}\end{array}$ & $\mathrm{t}^{\circ} \mathrm{C}$. & $\mathrm{pH}$ & $\mathrm{t}^{\circ} \mathrm{C}$. & $\mathrm{pH}$ \\
0 & $10 \cdot 3$ & $8 \cdot 19$ & $14 \cdot 43$ & $8 \cdot 24$ & $11 \cdot 15$ & $8 \cdot 16$ \\
5 & - & - & $13 \cdot 93$ & - & $11 \cdot 85$ & - \\
10 & - & - & $13 \cdot 69$ & $8 \cdot 23$ & - & - \\
15 & - & - & $12 \cdot 33$ & $8 \cdot 22$ & - & - \\
20 & - & - & $12 \cdot 19$ & - & - & - \\
25 & - & - & $12 \cdot 14$ & $8 \cdot 19$ & $11 \cdot 85$ & - \\
50 & - & - & $11 \cdot 81$ & - & - & - \\
75 & - & - & $11 \cdot 59$ & - & - & - \\
100 & $10 \cdot 39$ & $8 \cdot 19$ & $11 \cdot 57$ & $8 \cdot 17$ & $11 \cdot 85$ & $8 \cdot 17$ \\
& pH determined on 26th. & & & &
\end{tabular}

\begin{tabular}{clrcc} 
N 1 & \multicolumn{2}{c}{ July } & 11 th. & \multicolumn{2}{c}{ Nov. 8th. } \\
Depth. & $t^{\circ} \mathrm{C}$. & $\mathrm{pH}$ & $t^{\circ} \mathrm{C}$. & $\mathrm{pH}$ \\
0 & $16 \cdot 5$ & $8 \cdot 26$ & $11 \cdot 65$ & $8 \cdot 16$ \\
5 & $16 \cdot 38$ & - & $11 \cdot 74$ & - \\
10 & $16 \cdot 28$ & $8 \cdot 26$ & - & - \\
15 & $13 \cdot 64$ & $8 \cdot 25$ & - & - \\
20 & $11 \cdot 16$ & $8 \cdot 19$ & - & - \\
25 & $11 \cdot 09$ & - & $11 \cdot 73$ & - \\
50 & $11 \cdot 01$ & - & - & - \\
75 & $11 \cdot 01$ & - & - & - \\
95 & $10 \cdot 99$ & $8 \cdot 17$ & $11 \cdot 70$ & $8 \cdot 17$ \\
& & & \multicolumn{2}{c}{$\mathrm{pH}$ determined on 9th. }
\end{tabular}




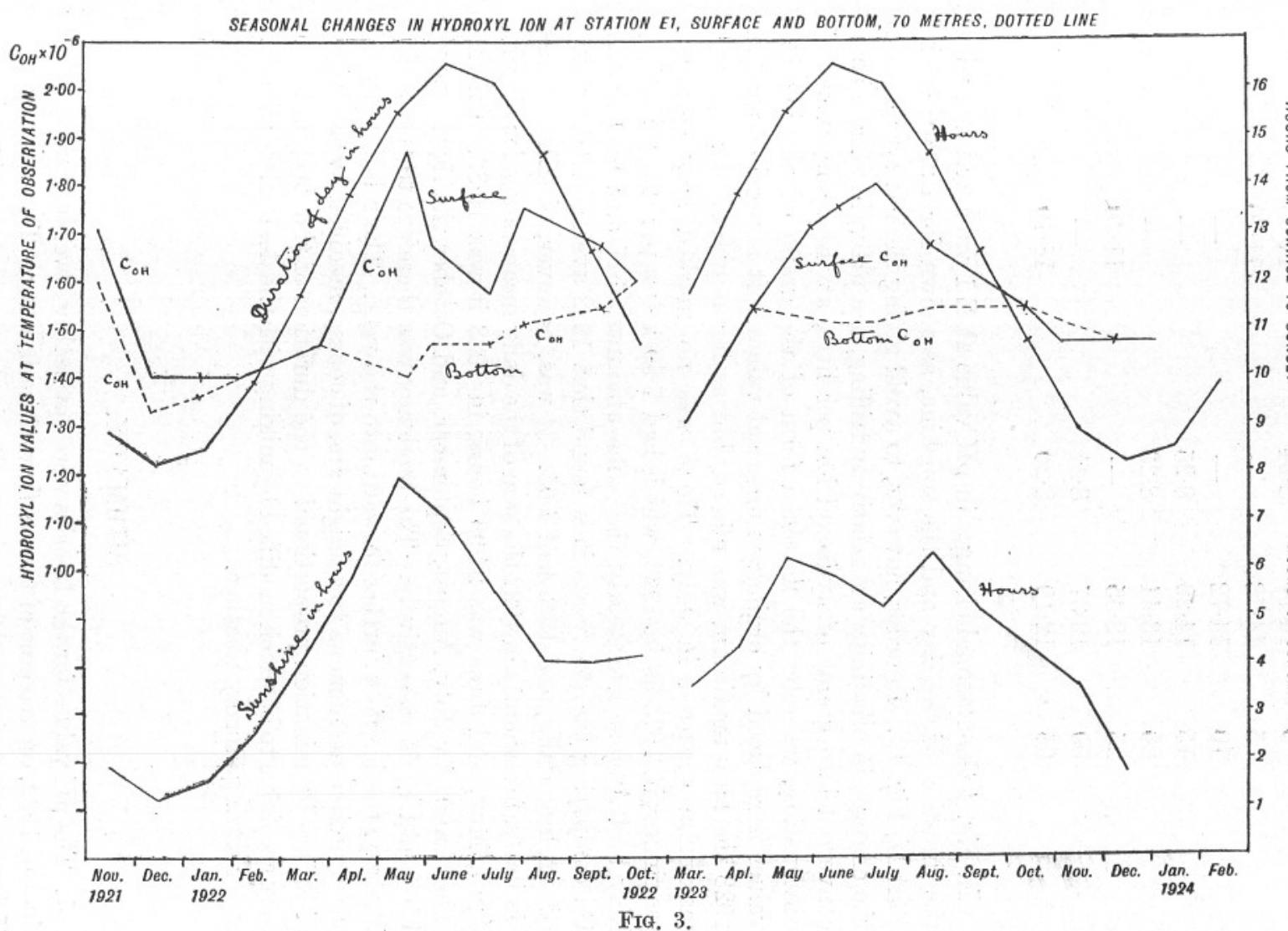




\begin{tabular}{clcc} 
N 2 & \multicolumn{2}{c}{ July 11th. } & Nov. 8th. \\
Depth. & $t^{\circ} \mathrm{C}$. & $\mathrm{pH}$ & $11 \cdot 65$ \\
0 & $14 \cdot 7$ & $8 \cdot 24$ & $11 \cdot 70$ \\
5 & $14 \cdot 78$ & - & - \\
10 & $14 \cdot 72$ & - & - \\
15 & $14 \cdot 29$ & $8 \cdot 25$ & - \\
20 & $13 \cdot 44$ & $8 \cdot 23$ & $11 \cdot 70$ \\
25 & $12 \cdot 35$ & - & - \\
50 & $12 \cdot 37$ & $8 \cdot 21$ & $11 \cdot 70$ \\
65 & $12 \cdot 19$ & $8 \cdot 20$ &
\end{tabular}

In Fig. 4 the seasonal changes in $\mathrm{pH}$ value at $\mathrm{E} 1$ are correlated with the duration of the day and the sunshine, as shown for 1922 alone in Part II, Fig. 12. In order, however, to avoid giving the impression that the changes in alkalinity are relatively trifling, the $\mathrm{pH}$ values have been converted into grams of hydroxyl ion per litre, at the temperature of observation, whereby the flattened form of the graph of the $\log 1 / \mathrm{H}$ values is replaced by ordinary numerical values. It is possible that in 1923 the May maximum was missed, but as far as observations go the maximum occurred in July. There was no marked May sunshine maximum in 1923 as in 1922, which had 7.90 hours per day; in 1923 May and August had nearly the same amounts, $6 \cdot 17$ and $6 \cdot 30$ hours. On comparing the two years it is found that 1922 averaged $4 \cdot 12$ hours of sunshine daily, and 1923 had 4.05. It was, however, distributed dissimilarly, for whereas in 1922 the sum of the daily mean values for March, April, May, and June was $24 \cdot 90$ hours, in 1923 it was $19 \cdot 82$. On the other hand, for July, August, September, and October the figures were $17 \cdot 78$ and $19 \cdot 65$ respectively. The tendency was therefore to throw the photosynthetic effect further forward into the year. The relationship of these surface phenomena to sunlight are, of course, modified by the effect of diffuse illumination proportional to the duration of the day, and also they are liable to be much modified by mixing with the deeper less alkaline water during stormy weather.

\section{SUMMARY.}

1. The $\mathrm{pH}$ values for the $\mathrm{L}$ series were noticeably lower in March, 1923, than in 1922, on account of the outflow of fresh water. The well-marked May maximum, followed by a depression in June and July, 1922, is not found in 1923, during the summer months of which the water increased in alkalinity until August, when it slowly decreased. This appears to be due to the absence of stormy and wet weather in June and July, 1923. 


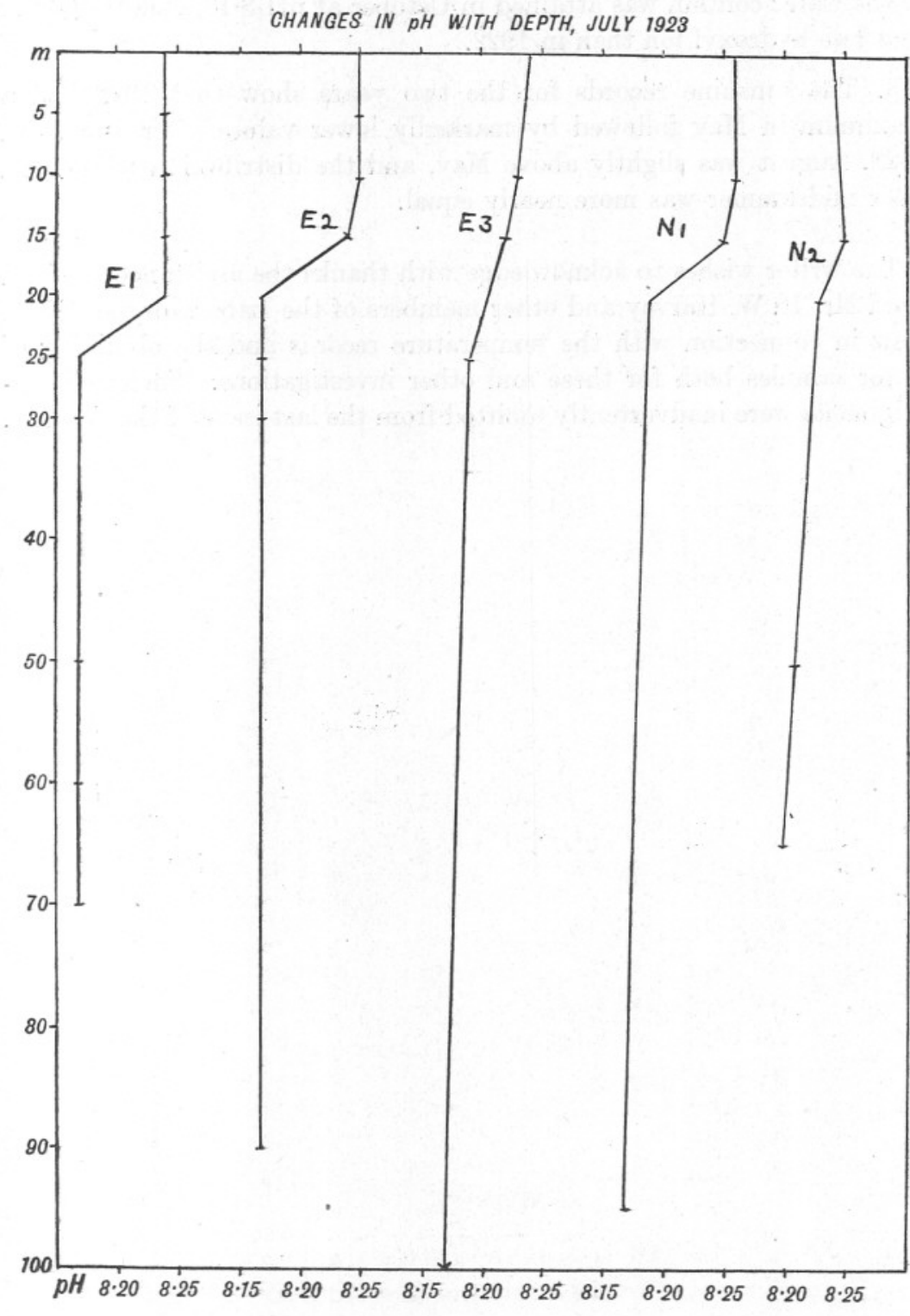

FIG. 4. 
2. The $\mathrm{pH}$ values for $\mathrm{E} 1$ reached their maximum at the surface in July, but the bottom values were still low. These increased till uniformity of the water column was attained in October at $\mathrm{pH} 8 \cdot 18$, denoting 3 per cent less hydroxyl ion than in 1922.

3. The sunshine records for the two years show that 1922 had a maximum in May followed by markedly lower values after June. In 1923, August was slightly above May, and the distribution before and after midsummer was more nearly equal.

The writer wishes to acknowledge with thanks the assistance received from Mr. H. W. Harvey and other members of the Laboratory staff and crew in connection with the temperature records and the obtaining of water samples both for these and other investigations. Such acknowledgments were inadvertently omitted from the last issue of the Journal. 